\title{
Imagen moderna y movimiento
}

\author{
Raúl EgUIZÁBAL \\ Universidad Complutense de Madrid
}

Recibido: $15 / 01 / 2015$

Aceptado: 10/02/2015

\section{Resumen}

Los medios modernos de comunicación implican el cruce entre dos hechos cruciales del pasado siglo, pero también de lo que llevamos de éste: la tecnología y el mercado de masas, entendiendo por «mercado de masas» no tan sólo una particularidad cuantitativa, también un tipo de relación entre productor y público (y hoy, así mismo, entre los propios consumidores) que hace tiempo dejó de ser de naturaleza interpersonal para convertirse en una relación mediada.

La relación entre el arte y los medios de comunicación tecnológicos, supone el encuentro entre dos tipos de prácticas, una de carácter fundamentalmente individual (lo que podemos entender por «experiencia estética») y otra básicamente social; entre una expresión prácticamente constante de la historia del hombre (quizá incluso de su prehistoria) y otra que es característica del mundo moderno, es decir de la sociedad que surge en el siglo XIX, cuyos atributos no han ido sino agudizándose a la par que extendiéndose en los siguientes siglos.

Para enfocar adecuadamente el tema de la vinculación entre el arte y la publicidad o los medios de comunicación, vamos a intentar fijarnos en un elemento que ha sido central del mundo moderno: el movimiento. Y quizá todavía más: la velocidad. Y cuando decimos central, nos estamos refiriendo a un componente que ha determinado tanto las conquistas tecnológicas como la vida social, el arte y la comunicación, el trabajo y los entretenimientos. Necesitamos pues remontarnos, aunque sea de manera sumaria, al origen de la era tecnológica.

Palabras clave: Arte, Publicidad, Historia, Movimiento, Medios de Comunicación. 


\title{
Modern image and movement
}

\begin{abstract}
The modern means of communication involve the intersection between two crucial facts of the last century, but also of this century: technology and the mass market, meaning «mass market» not only as a quantitative characteristic, is also a type of relationship between producer and audience (and today, also among consumers themselves) that long ago ceased to be interpersonal in nature and has now become a mediated relationship.

The relationship between art and technology media, is the meeting point between two types of practices, one fundamentally individual in nature (that we can understand by "aesthetic experience») and another basically social; between one that is a virtually constant expression of the history of humanity (perhaps even from its prehistory) and another that is characteristic of the modern world, i.e. of the society that emerged in the 19th century, whose attributes have not gone but deepened while stretching in the following centuries.

To properly focus the theme of the link between art and advertising or the media, we will try to look at an element that has been central to the modern world: movement. And perhaps even more: speed. And when we say central, we are referring to a component that has determined both the technological conquests as well as social life, art and communication, work and entertainment. We need to look back, although it will be in a summarized way, to the origin of the technological age.
\end{abstract}

Keywords: Art, Advertising, History, Movement, Media.

Ha asistido, el pasado siglo, a más cambios en todos los órdenes que en el resto de la historia del hombre. Y sin embargo, durante mucho tiempo se ha considerado inamovible el estatus del arte o, como dijo una vez Gillo Dorfles, «se ha seguido considerando como fenómenos artísticos aquellos que desembocaban en realizaciones de cuadros, estatuas, música de concierto, etc. sin tomar en consideración lo que interesaba o podía interesar al hombre de la calle de nuestros días, a nuestras «masas» ${ }^{1}$. Hace tiempo que llegó la hora de revisar ese estado de $\operatorname{cosas}^{2}$ y recordar que gran parte del arte del pasado tenía también una función narrativa e informativa, no muy distinta a la que hoy tienen algunos contenidos mediáticos, y que interesaba realmente al público de su época, no sólo a las clases dominantes, también al pueblo llano para quien, en buena medida, se habían encargado esas obras por razones convenientes (religiosas, sociales, políticas), es decir para hacerles participar de un determinado sistema de valores.

El cine, aunque a regañadientes, ha sido incorporado en ese Olimpo como el séptimo arte y todavía se discute en algunos mentideros si la fotografía constituye en realidad una forma de expresión de rango artístico. En verdad, resulta bastante fastidioso que todavía se siga haciendo girar la rueda de los privilegios para saber si ciertos discursos pueden entrar a forma parte o no del santuario del arte. Pero lo que parece obvio, es que resulta necesario terminar con ese pensamiento enviciado, tan peculiar de nuestra época, de que si algo interesa a las masas, de que si algo «se entiende», entonces no puede ser arte; y volver la mirada no sólo al cine y la fotografía, también a la publicidad y al diseño, a la música grabada o radiada, al cómic o al grafiti, para poder comprender lo que ha sido realmente el ciudadano del siglo en sus expresiones creadoras.

\footnotetext{
${ }^{1}$ Dorfles, G. (1974): Las oscilaciones del gusto, Barcelona, Lumen, 16

${ }^{2} \mathrm{Y}$ así se ha hecho en diversas ocasiones como en la exposición High and Low del MOMA (1991) o la de Art \& Pub del Centro Georges Pompidou (1989).
} 
La importancia del disco para el desarrollo de la música, a lo largo del siglo acaecido, ha sido, por ejemplo, extraordinaria; sin él, el jazz no se hubiese convertido en la música por excelencia del siglo XX. Por primera vez existía un documento sonoro, capaz de captar la capacidad de improvisación, capaz de resguardar una interpretación siempre diferente, y sobre todo capaz de promover una nueva categoría de interpretación resultante de un estado anímico, frente a la música del pasado ligada a una escritura inmutable. Todavía estamos, por cierto, esperando a que las nuevas tecnologías de grabación, conservación y transmisión sonora (mucho más accesibles que en la época de los vinilos) produzcan un tipo de música acorde con los nuevos tiempos. Todavía estamos por saber si la revolución de Internet constituye también una revolución creativa, una revolución en las formas discursivas, o tan sólo una revolución en las formas de distribución de contenidos y mercancías.

Para enfocar adecuadamente el tema de la vinculación entre el arte y la publicidad o los medios de comunicación, vamos a intentar fijarnos en un elemento que ha sido central del mundo moderno: el movimiento. Y quizá todavía más: la velocidad. Y cuando decimos central, nos estamos refiriendo a un componente que ha determinado tanto las conquistas tecnológicas como la vida social, el arte y la comunicación, el trabajo y los entretenimientos. Necesitamos pues remontarnos, aunque sea de manera sumaria, al origen de la era tecnológica.

Cuando los futuristas italianos se lanzaron al dominio plástico de la velocidad y al ensalzamiento de la máquina, no estaban sino haciéndose eco de una serie de conquistas científicas y sociales producidas a lo largo de todo el siglo XIX.

La aparición de la imprenta rotativa, que combinaba las aplicaciones del vapor, las tintas de imprenta y el papel barato a base de pulpa de madera, imponía esa misma velocidad a la edición de periódicos. En el mismo camino, el telégrafo acortó distancias, sentó el cimiento tecnológico de la futura radio, y proporcionó un medio de comunicación acorde con la velocidad que exigía la nueva sociedad industrial, y con la vastedad del imperio colonial británico y los nuevos Estados Unidos.

A la energía del vapor, se le unió la de la electricidad que durante años no había sido sino una curiosidad científica sin aplicación práctica. El telégrafo eléctrico de Samuel F. B. Morse permitió, desde 1844, la transmisión de señales (puntos y rayas) a través del cable. Bell fue quien logró la primera transmisión de voz humana a través de cable. Y el joven Marconi obtuvo las primeras emisiones sin hilos, aprovechándose del descubrimiento que unos años antes (1888) Heinrich Hertz había hecho de las ondas que llevan su nombre. Quedaba así, antes de cumplirse el siglo, establecido el fundamento tecnológico de la radio, pero la concepción de la radio como medio de comunicación de masas y no simplemente como forma de comunicación interpersonal, tardaría todavía unos años más. Aunque si pensamos un momento, todas estas invenciones que cambiaron la vida social y la vida doméstica en el siglo XIX, tuvieron como principio dirigente la conquista de la velocidad

\section{La bestia del apocalipsis}

La velocidad, pues, como la primera conquista del mundo moderno. Con la invención de la locomotora «The Rocket»(El Cohete) de George Stephenson, en 
1825 , la sociedad entró en la era de la velocidad, de las prisas, de lo cambiante y de lo efímero ${ }^{3}$. El ferrocarril no sólo revolucionó la economía y los sistemas de transporte, transformó la percepción del mundo, la naturaleza misma de la vida social.

La velocidad no sólo se sitúa detrás de la aparición de las nuevas formas de comunicación social y de la conformación de otras formas de relación social. Sus conquistas desbordan la esfera de lo tecnológico y de lo social y se insertan también en la esfera de lo artístico. La cultura y el arte ya no serán tampoco los mismos.

Una imagen (Turner. Lluvia, vapor y velocidad: el Great Western Railway, 1844) resume el poderío de las nuevas máquinas y expresa, al tiempo, la fascinación por el movimiento, por el dinamismo y la velocidad que sedujo a algunos artistas (no a todos) de mediados del siglo XIX, y que todavía parece constituir una obsesión al día de hoy.

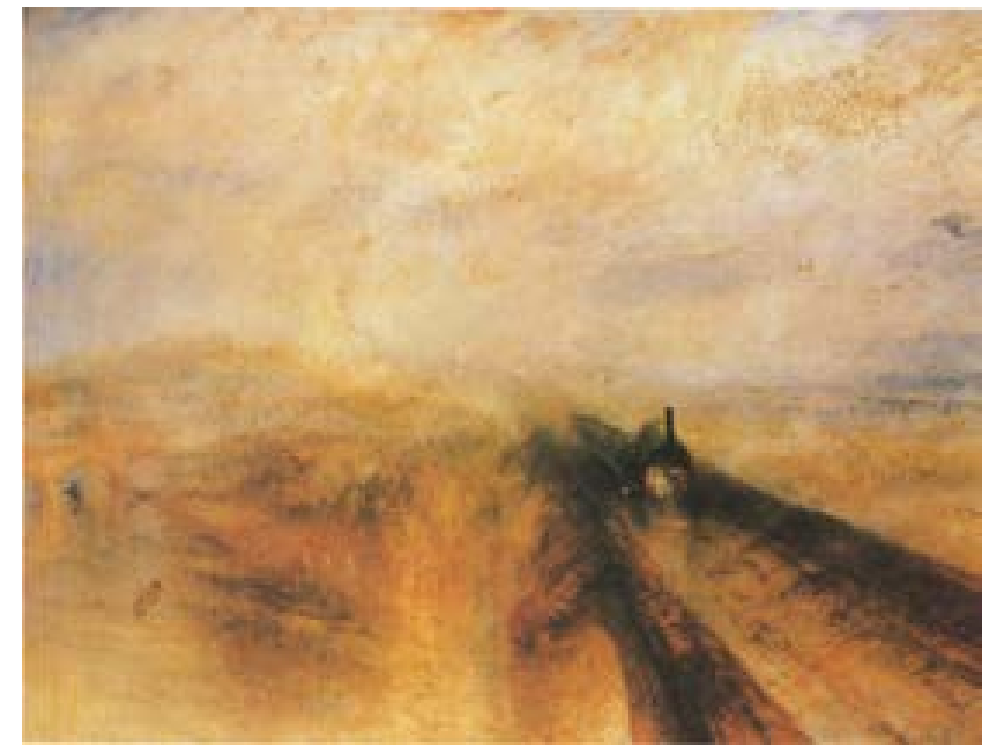

Fig. 1. Turner. Lluvia, vapor y velocidad: el Great Western Railway (1844).

La obra de Turner que -como dijo Constable- «parece pintada con vapor de colores» prefigura la de los impresionistas franceses y llega todavía más lejos que la mayoría de ellos en su abstracción de los fenómenos naturales. Mientras que para Gautier este cuadro representaba una «bestia del Apocalipsis» ${ }^{4}$, para Monet y Pissarro -quienes descubren la tela en un viaje a Londres, en 1870- constituyó toda una revelación.

\footnotetext{
${ }^{3}$ La primera locomotora de Stephenson, llamada «Blucher» se había ensayado en 1814.

${ }^{4}$ «Recordamos un boceto de Turner que vimos en Londres -decía Téophile Gautier- y que representaba un tren avanzando a todo vapor por un viaducto, en medio de una espantosa tempestad. Era un auténtico cataclismo. Relámpagos palpitantes, una suerte de alas de grandes pájaros de fuego, babeles de nubes derrumbándose bajo los rayos, torbellinos de lluvia vaporizada por el viento: parecía el decorado del fin del mundo. A través de todo esto se retorcía, como la bestia del Apocalipsis, la locomotora, abriendo sus ojos de vidrio rojo en medio de las tinieblas y arrastrando tras ella, como una cola inmensa, sus vértebras de vagones...»
} 
En cierto modo, no se hallaba Gautier demasiado lejos de la verdad, la máquina de vapor (hierro, humo y fuego) representaba el fin de un mundo, moroso y taciturno, que dejaba lugar a otro presidido por los apresuramientos, las urgencias y las zozobras, el mundo de las máquinas y la celeridad.

La máquina pintada por Turner era una modernísima «Patentee», construida por Stephenson, que llegaba a superar en pendiente los 130 kilómetros por hora. Una auténtica sensación de vértigo debía embargar a los pasajeros de la «Patentee», acostumbrados al pausado discurrir de las gabarras por los canales sembrados de esclusas y al trote de las caballerías arrastrando pesados carros y diligencias.

El paisaje impresionista no es, a la postre, sino el rastro de las sensaciones, la fugaz percepción del espectáculo de la naturaleza, visto desde la ventanilla de un tren lanzado a toda velocidad. Las formas se desdibujan y los colores parecen desgajarse de sus soportes. Cuando Víctor Hugo toma el tren por primera vez nota que «las flores ya no son flores, son manchas o más bien rayas rojas o blancas». Y el precursor pintor holandés Johan Barthold Jongkind escribe, tras un viaje en tren: «comprendí cómo era necesario pintar: no retener más que lo esencial de la luz sorprendida un segundo en diferentes momentos. Es suficiente la impresión fugitiva sobre la retina. Todo lo demás es inútil»» 5 .

Hasta el momento el objetivo de los pintores parecía haber sido el de la representación del espacio tridimensional. Tendemos a pensar que fueron los futuristas los primeros que acertaron (o al menos se empeñaron) en la representación de la velocidad. Pero ya los pintores del Impresionismo, y alguno de sus precursores como Turner, convirtieron el movimiento en un interés central de su arte, adivinando que los tiempos venideros eran los de la movilidad, el dinamismo y la acción. Tiempos convulsos, tiempos de cambio, en más de un sentido. Acaso la diferencia fundamental entre unos y otros es que los artistas del XIX buscaban pintar la «impresión» de la velocidad, la huella de la velocidad sobre los sentidos, mientras que los futuristas y otras vanguardias del siglo XX buscaban reproducir el movimiento directamente, bien con representaciones estáticas o dinámicas.

Por supuesto que Turner se topó con un muro de absoluta incomprensión hacia su cuadro, tanto por el horrísono tema como por el innovador tratamiento. Treinta y dos años más tarde, Monet realizaría una serie de doce pinturas sobre la estación de Saint-Lazare en las que nuevamente los protagonistas son el vapor y la máquina. Y todavía más adelante los futuristas se lanzarían con toda clase de pertrechos, incluida la fotografía, a mostrar la velocidad de trenes, automóviles, motocicletas, etc.

Podemos pensar que la mirada impresionista estuvo, en efecto, afectada por esas veloces imágenes desde el tren. Interesados por plasmar la vida contemporánea, los artistas del Impresionismo querían captar el instante fugaz, el paso veloz de la luz por los paisajes y el cambiante fluir de los colores.

El impresionismo exigió pintar más deprisa, el apunte rápido, la instantánea, a la manera de la naciente fotografía. La llegada a Europa de las estampas coloreadas

${ }^{5}$ Charbonnier, J. M. (1991): «Le Siècle de fer» en Grandes lignes: quand l'art entre en gare, Paris, Publications Nuit et Jour, 14-15. 
japonesas, con sus escenas de la vida cotidiana recogidas en rápido y nervioso trazo, $\mathrm{y}$ su desdén por el acabado perfecto, supuso otra fundamental influencia.

Pero no todo fueron alabanzas para la nueva era de la máquina. Una serie de artistas e intelectuales entre los que se encontraban Dickens, Wordsworth, Ruskin, Delacroix o el citado Gautier contemplaban la llegada del ferrocarril como un Apocalipsis. Apocalípticos e integrados, por emplear la terminología de Eco, se enfrentaban ya al promediar el siglo XIX. Y sin embargo una revolución como la que se estaba produciendo no es que afectase únicamente a la nueva pintura: obligaba a una revisión de lo ya pintado. "Ya no era posible ni deseable "leer" los cuadros y los dibujos con la delectación y minuciosidad con que se hacía en el pasado» ${ }^{6}$. No era simplemente una aceleración de los procesos económicos y sociales, era también una nueva percepción, una nueva manera de ver la vida, el arte y el mundo.

Como si se tratase de alguna nueva clase de embriaguez, el ser humano se ha dejado seducir por ese espejismo que es la velocidad, materializado primero en la aparición del ferrocarril, luego del automóvil, del avión o, en tiempos mas recientes, del tren de alta velocidad, del cohete y del satélite.

El movimiento no tiene, sin embargo, sólo un valor puramente corporal o mecánico. Se expresa también en la aparición del cine y los medios de comunicación, en la acelerada narrativa publicitaria, en la velocidad a la que circula la información, en la percepción fragmentaria e instantánea a la que nos han acostumbrado los medios, en el ritmo acelerado con que se suceden las modas, los estilos, en la instantaneidad y fugacidad de la fama. Tiene por lo tanto un valor a un tiempo psíquico, estético y social, además de físico.

Pero fue con las vanguardias del siglo XX, esencialmente con el cubismo y el futurismo, y otras escuelas derivadas de éstas, con las que el movimiento se convirtió en obsesión.

A este desvelo por las consecuencias perceptivas y emocionales del movimiento no le fue ajena la llegada de formas renovadas de comunicación y expresión como la fotografía y el cine. Ambas fruto del desarrollo tecnológico de la época, frente a la querencia de muchos artistas y espectadores por las maneras tradicionales de la representación.

En el albor del siglo XX, en aquellos países donde la Revolución Industrial era ya un hecho, las fábricas se encontraban produciendo mercancías por miles y las prensas de los grandes periódicos tiraban cientos de miles de ejemplares. En 1902, En Estados Unidos, Cosmopolitan circulaba 700.000 ejemplares; Delineator, 960.000 y Ladie's Home Journal alcanzaba la cifra del millón de ejemplares.

En el tiempo de la velocidad resulta inevitable la preponderancia de lo visual, un canal más rápido transportando información, que se manifiesta en la profusión de las revistas ilustradas, en la aparición de la tira cómica (1896), y en el éxito de los carteles cromolitográficos que inundan las calles de las grandes capitales. El protagonismo de la imagen va a ir creciendo ayudado por la fotografía, el cine y la televisión. Las lecturas se vuelven fáciles y digestivas. Al mismo tiempo que la reproducción mecánica o posteriormente electrónica, permite un mayor número de acercamientos a una obra,

${ }^{6}$ Ramírez, J.A.(1988) Medios de masas e Historia del Arte, Madrid, Cuadernos Arte Cátedra, 54. 
estos se vuelven más breves. Una nueva forma de ver el arte y de relacionarse con personas y objetos, con urgencia, sin sosiego.

El entorno se satura de mensajes rápidos, avisos, comunicaciones, letreros luminosos, imágenes fugaces que se extinguen con la misma urgencia que aparecen, aunque también con la posibilidad de ser vistas en momentos sucesivos. La pintura simultaneísta, con su yuxtaposición de sensaciones visuales, la poesía de Apollinaire (Las ventanas, 1918) o la de Cendrars (Prosa del transiberiano y de la pequeña Juana de Francia, 1913), los collage y montajes dadaístas o novelas como Manhattan Transfer (1925) y la Trilogía U.S.A. (1937) de John Dos Passos parecen querer atrapar esta superposición de impresiones fugaces.

El proceso de aceleración social no se detuvo a lo largo de todo el siglo XX: el automóvil, el avión, la televisión, el vídeo, el tren de alta velocidad. Pero también los alimentos precocinados, las bebidas instantáneas, la moda y los anuncios comerciales. La aspiración no es ya la de movimiento o velocidad, sino la de instantaneidad. A la comida instantánea (lista para el consumo), le sigue la instantaneidad mediática de Internet. Del congelador al plato, pasando por el microondas. Del productor espontáneo de contenidos al auditorio más grande de todos los tiempos, pasando por la web. Todavía mejor, no es necesario comprar, ni cocinar, ni mucho menos ensuciar: en un momento lo puedes tener en tu domicilio con un clic. Los canales de distribución tradicionales se tambalean, el comercio tradicional, el restaurante, la sala de cine, incluso los grandes almacenes bailan sobre un pie ante el poder de la instantaneidad que representa el comercio online. El reto es hacerlo cada vez más rápido, con un mínimo de pulsaciones del ratón y en un tiempo record.

Desde el primer momento pareció extenderse una rivalidad entre lo que suponían las nuevas conquistas tecnológicas y sus posibilidades expresivas, su margen de libertad creativa pero también su profundo reflejo de los cambios que se estaban produciendo en el mundo moderno, y las formas expresivas tradicionales como la pintura, el teatro o la arquitectura.

Ahora estamos en disposición de extraer dos conclusiones que espero se vean suficientemente explicitadas a lo largo de las siguiente líneas: el retardo y la resignación del arte tradicional (entendiendo por tal el que se mantuvo fiel a las tecnologías históricas del lienzo y la piedra) frente al nuevo arte surgido del choque entre las nuevas tecnologías (eléctricas, fotoquímicas, electrónicas) y el mercado de masas. Y la superioridad de éste último para expresar todas aquellas cosas que el arte tradicional quería exponer como imagen del mundo moderno, pero en lo que se veía rezagado precisamente por sus pretéritos recursos tecnológicos.

Pero primero una consideración: en el fondo no existen diferencias insondables entre aquellos artistas llamados de vanguardia -léase, por ejemplo, un Juan Gris o un Depero- y aquellos otros que se mantuvieron aparentemente más fieles a una concepción histórica del arte -como un Balthus, sin ir más lejos-. Es decir, aunque los mensajes perteneciesen a categorías bien diferentes, el uso de los mismos medios suponía la imposibilidad de ponerse a la altura del momento social, en un entorno donde el medio condicionaba mucho más que el mensaje. 
Y segundo, una sospecha: que el auténtico arte del siglo XX (entendiendo por tal aquel que mejor lo representa) no lo constituyen aquellas obras que se mantuvieron fieles a los formatos y a las tecnologías del arte surgido en el Renacimiento, sino aquellas otras como el cine, la fotografía, el cómic o el diseño que son una consecuencia y un reflejo, al tiempo, de la sociedad industrial, y dibujan con mucha mayor precisión la naturaleza o condición del siglo en lo que han sido sus conquistas y sus fracasos. Esto es, que no solamente el arte reproducido técnicamente puede ser arte (siempre y cuando haya sido concebido como tal), sino que constituye el arte necesario de un siglo, a su vez, dominado por la producción técnica.

\section{De la fotografía como arte}

Esa rivalidad de la que hablábamos se sintió en primer lugar entre la fotografía y las artes tradicionales del lienzo y el papel.

Los primeros pasos firmes de la fotografía profesional se dirigieron hacia el retrato del que fue desplazando a la pintura de corte más académico.

Al ferrocarril, el telégrafo y los sistemas de impresión rotativa, como expresiones tecnológicas de la conquista de la velocidad, habría que añadirle pues la fotografía. La fotografía fue inventada por pintores -eso sí, por pintores mediocres- buscando un camino más fácil al problema de la representación del mundo real sobre una superficie de dos dimensiones.

La cámara oscura, de la que la fotografía es heredera, había sido un utillaje de pintores y dibujantes desde antiguo. Su mecanismo fue explicado por Leonardo y, en 1588, Giovanni Battista della Porta le incorporó una lente para hacer la imagen más luminosa. Fue de uso frecuente entre los pintores holandeses de la segunda mitad del siglo XVII. Los creadores de la fotografía, Niepce, Talbot, Daguerre, no hicieron sino fijar químicamente la imagen que recogía la cámara oscura.

La fotografía se convirtió en la sirviente de la pintura, descargando a ésta del problema del tiempo y el dinero que conlleva un modelo. "Su verdadero deber -expresaba Baudelaire en "El público moderno y la fotografía"- es el de ser la sierva de las ciencias y de las artes; pero la muy humilde sierva, como la imprenta y la taquigrafía que no han creado ni suplido a la literatura» ${ }^{7}$.

Sometida a este modesto papel, la fotografía fue bien acogida por los artistas en un principio y utilizada como documento o apunte complementario. Prácticamente todos lo pintores de la época, Courbet, Delacroix, Ingres, Millet, etc. la emplearon, si exceptuamos los impresionistas interesados en traducir directamente las impresiones de la naturaleza, pero incluso entre estos Monet, Cezanne, Degas se valieron de ella. En algunos casos emplearon fotografías ya realizadas -ciertos fotógrafos se especializaron en desnudos y motivos destinados a los pintores- y en otros casos las hicieron ellos mismos. Rosseti, Burne-Jones y Degas ampliaron fotográficamente sus dibujos para evitarse el engorro de la reproducción a escala cuadriculada.

Los conflictos empezaron cuando la fotografía desafió a la pintura queriendo instituirse ella misma como un arte. Los pintores (de entre los cuales Delacroix se desmarcó) firmaron en 1853 un manifiesto en contra de cualquier reconocimiento de

\footnotetext{
${ }^{7}$ Baudelaire, Ch. (1988): Curiosidades Estéticas, Ed. Júcar, Barcelona, 231.
} 
la fotografía como arte. Y, con motivo de su inclusión en el palacio de la Industria, en 1859, en salas próximas a las del Salón anual de la pintura, Baudelaire lanza su famoso panfleto: «como la industria fotográfica era el refugio de todos los pintores fracasados, demasiado mal dotados o demasiado perezosos para acabar con sus estudios, esta pasión universal entrañaba no solamente el carácter de la ceguera y la imbecilidad, sino que también tomaba el color de una venganza» ${ }^{8}$.

La fotografía, descendiente al fin y al cabo de la pintura, inició su andadura apoyándose en la tradición pictórica más antigua, constituyéndose realmente en la conservadora de la «mirada renacentista». El «ojo único» de Brunelleschi, el agujero de la cámara oscura y el objetivo de la máquina fotográfica son prácticamente la misma $\operatorname{cosa}^{9}$. Pero, por ello mismo, liberó a la pintura de la esclavitud de la «realidad». Una realidad que no era sino un convencionalismo creado por los artistas del Quatroccento.

La fotografía vulgarizó el retrato, y lo que era un privilegio y un elemento de distinción de clases pudientes, se terminó convirtiendo en algo muy popular. La fotografía democratizó, en cierto sentido, el retrato, lo hizo fácil y barato, y al mismo tiempo provocó la desaparición del género del retrato en miniatura. Sobre 1.300 pinturas expuestas en la Royal Academy en 1830, había trescientas miniaturas; en 1870 sólo treinta y ocho ${ }^{10}$.

Es de suponer que algunos pintores (los más «mecánicos» precisamente) se quedaron sin trabajo como consecuencia del advenimiento de esta nueva tecnología, pero también empujó a la pintura a buscar caminos a los cuales la fotografía no pudiese seguirle. El arte moderno empezó a liberarse del referente, o mejor de la apariencia de realidad, dispuesto a constituirse en su propio referente, en objeto en sí mismo.

Sin embargo, lo que causó reacciones furibundas no fue el que la fotografía ocupase, con ventaja, un espacio que hasta entonces había sido ocupado por pintores profesionales, sino su pretensión de instituirse como un nuevo arte.

Es obvio que la tras la consideración de «Arte» se encontraban más cosas que el que aquellos fotógrafos pudiesen llamarse a sí mismos «artistas». El reconocimiento social, el respeto institucional, poder formar parte de los Salones oficiales y, por supuesto, una valoración económica más generosa de su trabajo estaban detrás de ello. Aunque en realidad pienso que, todo esto, a quien exclusivamente preocupaba era a los artistas plásticos, detentadores únicos hasta aquel momento de la palabra Arte en cuanto a la imagen plástica se refiere, y que a los fotógrafos les interesaban más otras cosas, como las de resolver algunos problemas técnicos y perceptivos, descubrir los límites y posibilidades de su nueva industria y procurar rentabilizar económicamente su práctica.

Pero el desquite de la fotografía ante la resistencia de aquellas formas artísticas socialmente establecidas, nunca fue, en realidad, su siempre discutida validez artística ${ }^{11}$, sino la influencia que, en verdad, ha ido ejerciendo en el discurrir del arte moderno, y sobre todo su superioridad a la hora de alcanzar determinados objetivos propuestos por los venideros movimientos de vanguardia.

\footnotetext{
${ }^{8}$ Baudelaire. Ch. (1988): Curiosidades Estéticas, Barcelona, Ed. Júcar, 230.

9 Juan Antonio Ramírez (1988): Medios de masas e historia del arte, Madrid, Cátedra, 168.

${ }^{10}$ Según datos del Diccionario Larousse de la Pintura, Barcelona, Planeta-De Agostini, 678.
} 
La gran convulsión se produjo con la llegada primero de la instantánea en 1859, por los mismos años en que hacía su aparición el Impresionismo. Luego, con la cronofotografía.

Al mismo tiempo que se redujo el tiempo de exposición, los equipos fotográficos se volvieron más ligeros y manejables permitiendo otros puntos de vista diferentes al frontal. «La cámara ayudó a descubrir el encanto de las vistas fortuitas y los ángulos de visión inesperados» ${ }^{12}$.

Degas, un dibujante de excepción, fue de los más influidos por la cámara, buscando difíciles escorzos, composiciones singulares, cortando a veces las figuras (como también hacía la estampa japonesa, la otra gran inspiración de la época) y captando a sus personajes en posturas totalmente alejadas de las académicas. Fotografías como las de Hippolyte Jouvin, inspiraron los primeros temas impresionistas y los cuadros de pintores como Pissarro. Tomadas desde lejos, se descubría en ellas a las figuras en posturas que nunca habían sido recogidas por la pintura, difíciles de captar incluso para el ojo humano. Degas buscaba en sus telas y pasteles esta misma expresividad de los cuerpos captados en actitudes familiares, del cuerpo que no se sabe mirado.

Este cartel (Fig. 2) fue encargado a Lautrec por su amigo el escritor Victor Joze para anunciar su novela Reine de Joie. Moeurs du Demi-Monde (Reina de la alegría: costumbres mundanas). Captaba las escenas callejeras o de la vida en el café a la manera de un fotógrafo. Apenas unos pocos trazos servían para plasmar con exactitud todo el bullicio de la Belle Epoque. Composiciones diagonales, atrevidos escorzos, a la manera de Degas, y una simplificación que estaba influida por la publicidad litográfica. En el nuevo arte del cartel, Lautrec aprendió a trabajar con una economía de medios propia de la era de la velocidad.

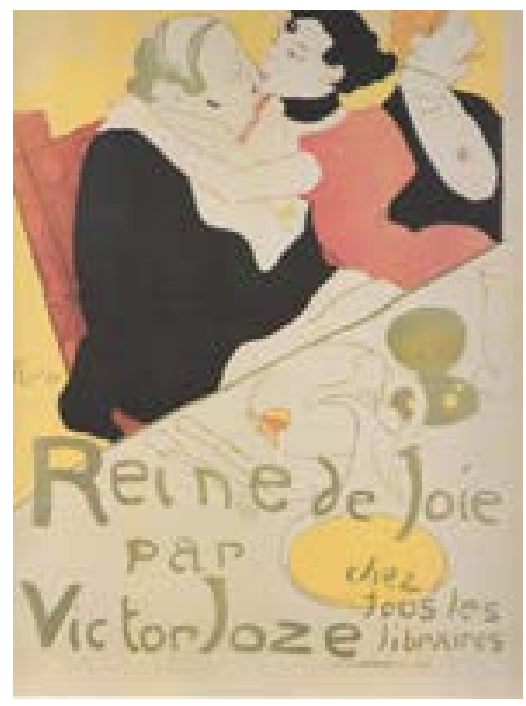

Fig. 2. Toulouse Lautrec. Reine de Joie, 1892.

${ }^{12}$ Gombrich, E.H. (1982): Historia del arte, Madrid, Alianza Forma, p. 441. 
Lautrec formó parte de los nuevos artistas interesados por la fotografía, y especialmente por la de su amigo el fotógrafo Maurice Joyant. Atraído -al igual que Degas- por la estampa japonesa, en su estilo convergen ambas influencias. A pesar de que su trazo tiende a lo caricaturesco, Lautrec no está menos determinado por la fotografía que Degas u otros artistas de su tiempo. Las figuras aparecen congeladas en insólitas actitudes, las composiciones son igualmente atrevidas y, como un fotógrafo documental pero sin sus ataduras formales, Lautrec va levantando una galería de tipos y costumbres parisinos. Precisamente en el cartel que hizo como regalo para su amigo el fotógrafo Paul Sescau descubrimos las peculiaridades de su estilo instantánea: la figura de la mujer y la del fotógrafo aparecen sorprendidos por el artista en un dibujo veloz que no quiere dejar escapar el gesto de ella ocultándose a la cámara o el de él, abiertas las piernas frente al trípode y la cabeza oculta bajo la manta.

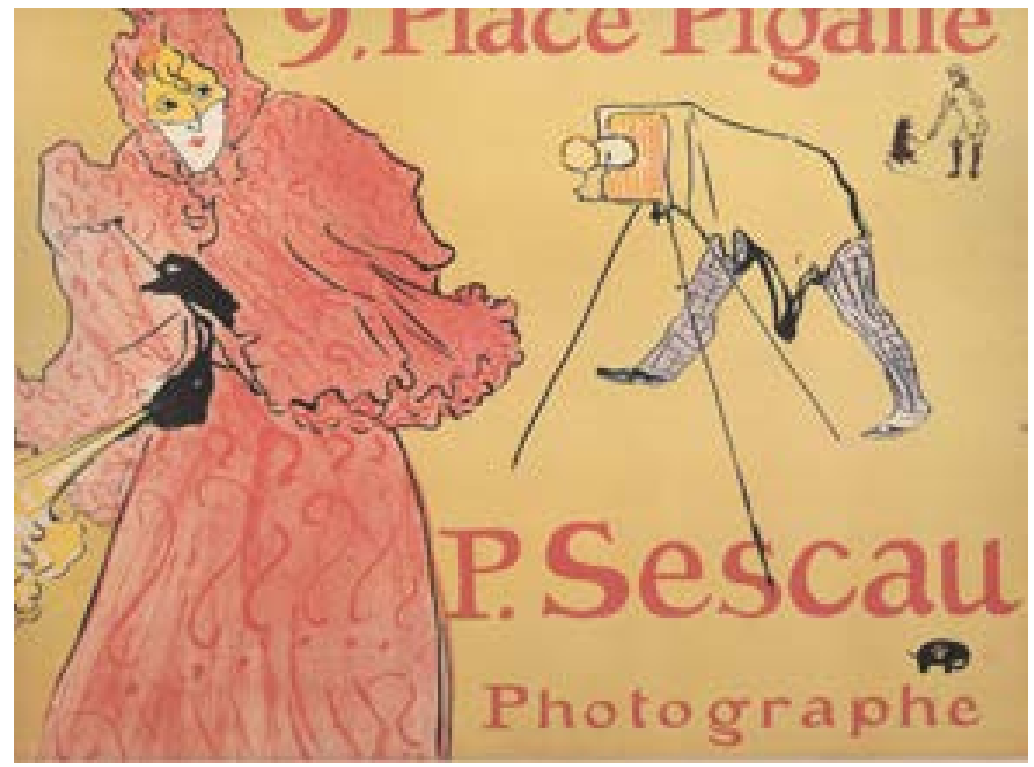

Fig. 3. Toulouse Lautrec. P. Sescau. Photographe, 1894. 60x80 cm.

Lautrec utilizó a menudo fotografías como base para sus obras. Este otro cartel (Fig. 3) fue, como decimos, un regalo para su amigo y fotógrafo Paul Sescau, anunciando su estudio. La mujer aparece en el acto de ser retratada por una intrusiva cámara. Sescau apareció así mismo en otras obras del pintor, como el bigotudo intérprete de banjo en un menú diseñado por Lautrec para el restaurante «La Bouillabaisse», y como espectro en uno de los paneles que pintó para un circo en que trabajaba La Goulue (1895). Una segunda versión del cartel muestra a la modelo con un velo amarillo o máscara, y un tercero tiene también un estrafalario pequeño motivo de una mujer desnuda con un látigo y un cerdo artista (¿la propia Goulue?).

Estos, y otros, artistas demostraron su gigantesco talento a la hora de captar las ventajas que les aportaba la nueva tecnología. En vez de iniciar una guerra, perdida de 
antemano, intentando detener el desarrollo de la fotografía como medio de expresión, supieron utilizar en su beneficio los provechos que podía aportar a su arte.

A partir de la década de 1880, los medios de impresión permitieron la reproducción de fotografías a un precio razonable, pero fue sobre todo con la entrada del nuevo siglo cuando la fotografía pasó a constituirse como parte de la prensa cotidiana $\mathrm{y}$, con el tiempo, de la publicidad. Realmente la fotografía no conquistó la publicidad hasta pasada la Segunda Guerra Mundial, es decir al mismo tiempo que se producía el nacimiento de la sociedad de consumo.

La publicidad y sus aliados naturales, los medios de comunicación, contribuyeron a la conformación de una nueva sociedad que hacía del consumo el eje alrededor del cual iba a girar no sólo la vida económica, también la cultural y social. La crisis de 1929 había demostrado que era insostenible mantener un sistema sustentado únicamente en la producción, sino se creaba un consumo paralelo que restableciese el equilibrio. Desde los años 50, la socialización en el consumo -cuyo instrumento fundamental es la combinación de publicidad y medios de comunicación- modificó el sistema de valores del capitalismo tradicional (el trabajo, el ahorro) para sustituirlo por otro (el ocio, el derroche, la acumulación) iniciando el camino hacia la sociedad postindustrial.

\section{Fotografía y movimiento}

Un curioso y antiguo problema pictórico, aunque también científico, el de saber si un caballo al galope separaba las cuatro patas del suelo a un tiempo, empujó a una serie de fotógrafos científicos a utilizar la fotografía con el fin de descomponer el movimiento. El primero fue el americano Eadweard Muybridge quien, en 1877, construyó una batería de cámaras (entre diez y treinta) que iban disparándose según el animal rompía una serie de hilos atravesados. Más adelante empleó un mecanismo de relojería con idénticos resultados: una serie de fotografías, cada una de las cuales recogía al animal en un instante de su carrera.

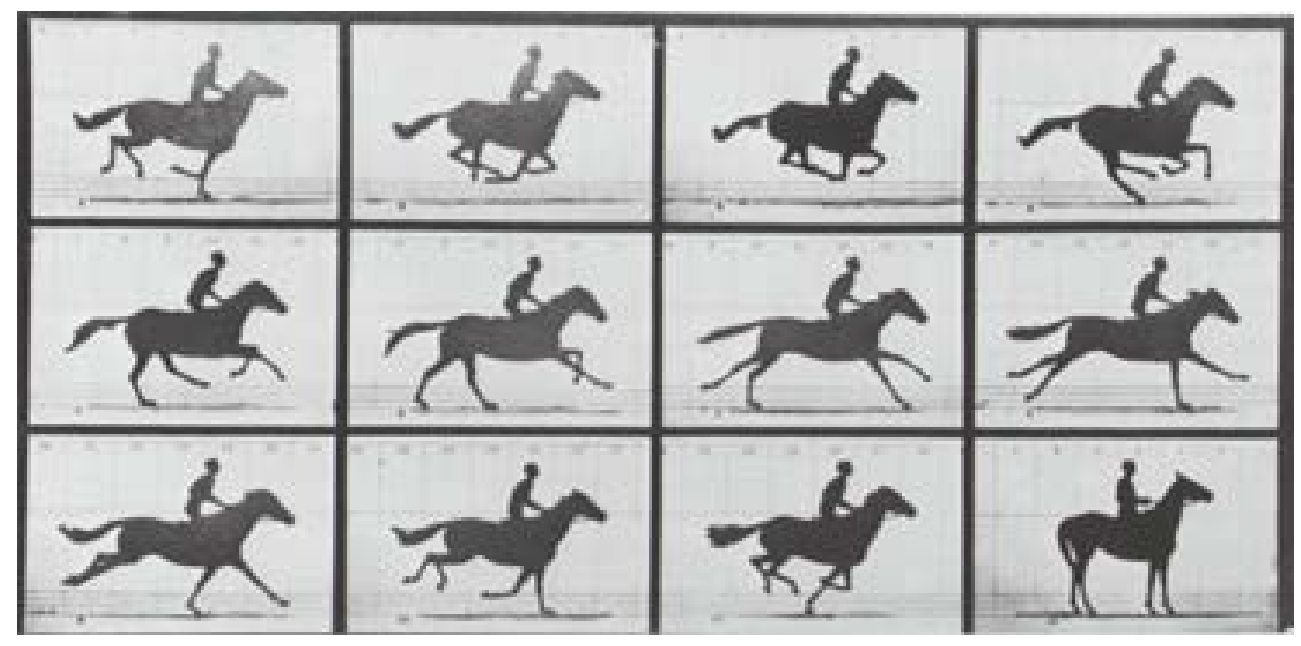

Fig. 4. Eadweard Muybridge: secuencias fotográficas de un caballo. 
En todas las formas comunicativas hay siempre una primera etapa muy experimental, en la que sus practicantes intentan comprobar el alcance de la todavía reciente tecnología. Con esta imagen (Fig. 5), Muybridge se adelantó a los experimentos del cubismo (y de algún fotógrafo futurista y constructivista), al menos en un par de décadas. En este caso, lo que se movió fue el punto de vista para obtener una serie de imágenes tomadas al mismo tiempo desde tres lados.

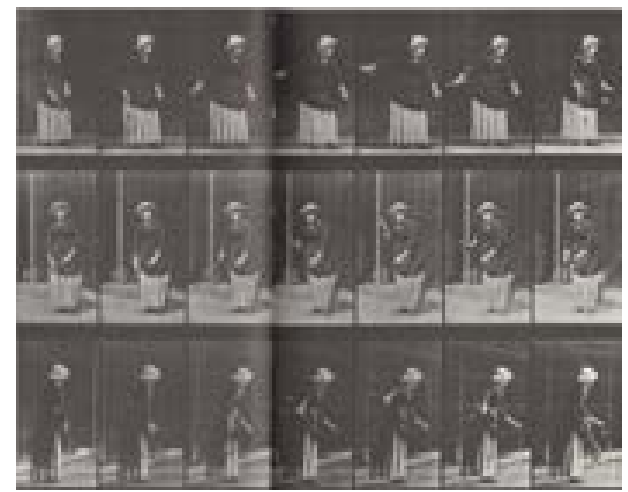

Fig. 5. Secuencias de Muybridge de una mujer jugando al tenis, fotografiada sincrónicamente desde tres puntos de vista. Tomadas entre 1872 y 1885.

Si en vez de resolver el experimento en una serie de placas, Muybridge hubiese obtenido las imágenes sobre una misma placa, habría conseguido la primera imagen cubista de la historia.

El alemán Ottomar Anschütz, años más tarde (1884) realizó también descomposiciones fotográficas del movimiento mejorando la calidad de las fotos. Pero aunque algunos de estos experimentos de análisis del movimiento fuesen conocidos por los artistas de vanguardia, la inspiración no vino de las series fotográficas sino de las cronofotografías del fisiólogo Étienne-Jules Marey. En ellas el investigador empleaba un aparato con placas fotográficas inmóviles, en el cual las imágenes momentáneas se reproducían unas junto a otras en una sola superficie. El movimiento aparecía descompuesto sobre una única placa.

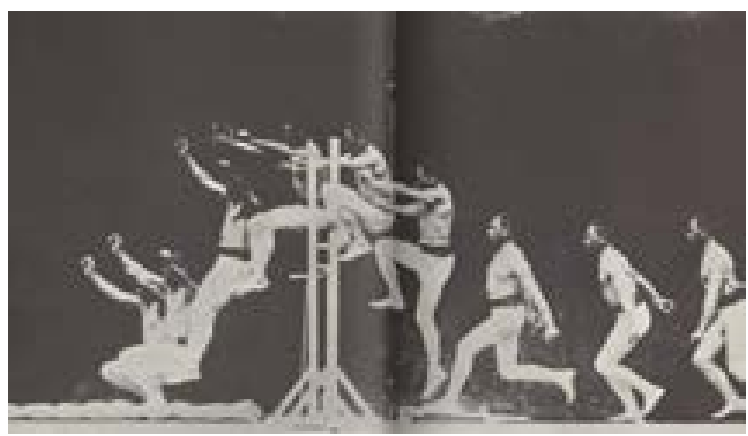

Fig. 6. Cronofotografía de Marey. 1882 
El ascendente de Marey en Desnudo bajando una escalera (1911) de Duchamp (Fig. 7), obra en la que el artista combina los principios del cubismo y el futurismo, parece obvio. En las primeras décadas del siglo, los artistas, entre los que se contaban cubistas y futuristas, y otros como Kupka o el propio Duchamp, intentaban atrapar el movimiento, y con él el paso del tiempo, en sus cuadros. Es difícil que esos experimentos hubiesen sido posibles sin los antecedentes fotográficos citados.

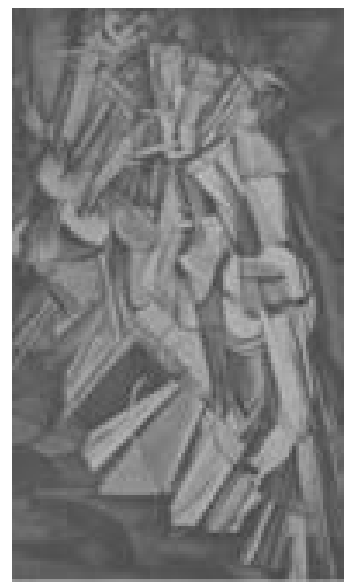

Fig. 7. Duchamp. Desnudo bajando una escalera. 1911

Las preocupaciones de ciertos pintores en las primeras décadas del siglo XX, pues, eran las mismas que las de los fotógrafos experimentales (es decir, los no pictorialistas) de las décadas finales del siglo XIX. Si nos fijamos, por un momento en el cuadro (Fig. 8) de Robert Delaunay, Formas circulares (1913), los círculos y sus sectores pintados de colores puros comunican una sensación visual de movimiento, pero lo hacen, sin duda, de una manera mucho mas torpe que las fotografías de Marey o de Thomas Eakins. Podrá, sin duda, argumentarse que en una pintura hay muchas más cosas además del programa del cuadro (la factura, el aspecto emocional del color, etc.) Sin duda, pero lo cierto es que fueron precisamente aquellos fotógrafos que carecían de pretensiones artísticas, los que se adelantaron con sus estudios y experimentaciones a los propósitos de estos artistas.

Cierto que los futuristas renegaron de los descubrimientos de la fotografía, y del fotodinamismo en concreto. La expulsión del grupo futurista de Anton Bragaglia, un continuador estético de los descubrimientos científicos de Marey, a raíz de la publicación de su obra Fotodinamismo futurista (1913) no puede hacernos olvidar que unos años antes Anton y su hermano Bruno Bragaglia estaban exponiendo con los pintores futuristas y trabajando en colaboración con Balla. Este último, buscaba en sus pinturas la sensación de movimiento y de ritmo mediante la descomposición en fases de la imagen. 


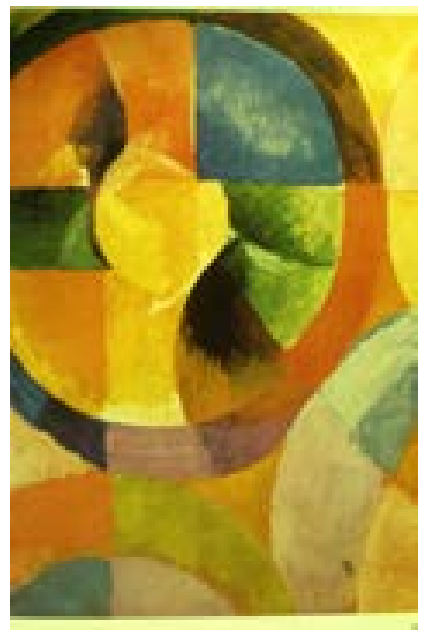

Fig. 8. Robert Delaunay. Formas circulares, 1913.

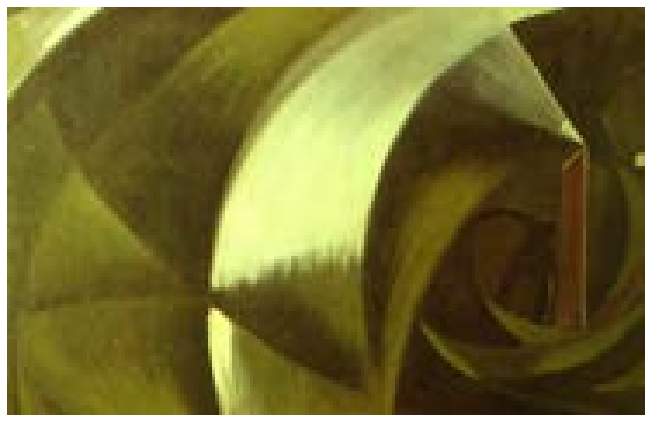

Fig. 9. Giacomo Balla. Arboles mutilados, 1918.

Pero si comparamos el cuadro de Balla (Fig. 9) con la siguiente imagen de Bragaglia (Fig. 10) comprobamos cómo la fotografía, un medio auténticamente moderno en la época, se muestra superior a la hora de transmitir con naturalidad aquellas acciones que pretendían los futuristas. 


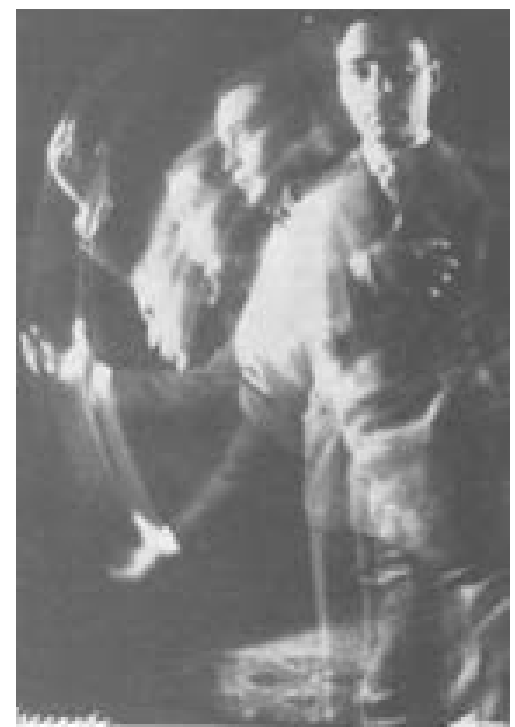

Fig. 10. Anton Giulio Bragaglia. El saludo. 1913.

La opción de los cubistas fue diferente. En ellos (Fig. 11), lo que se movía no era el objeto sino el observador. La suma de los puntos de vista ofrecía un aspecto descompuesto, facetado de la realidad. El montaje fotográfico, impresionando sucesivas veces un mismo negativo, obtenía sin embargo resultados muy semejantes, y de manera mucho más cómoda.

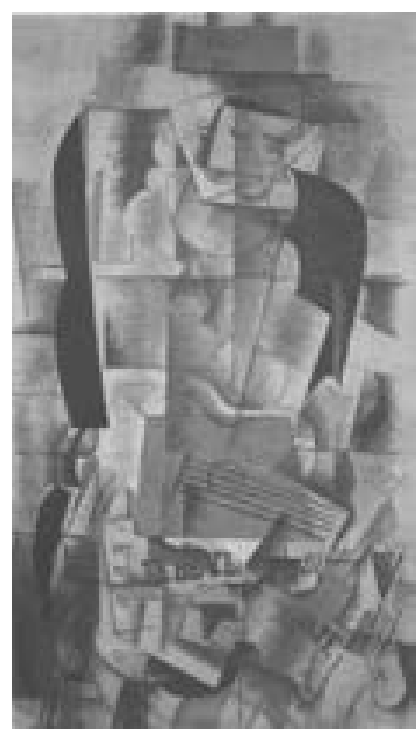

Fig. 11. Georges Braque. Mujer con guitarra. 1913. 
La observación más simple nos demuestra que todos estos atrevidos experimentos cubistas o futuristas, que emplean en su ejecución tecnologías pretéritas, resultaban equívocos en sus ideales e incluso malogrados en sus finalidades, si los comparamos con la eficacia de los resultados fotográficos. El constructivista Rodchenko empleaba en este retrato del artista Alexander Svenchenko (Fig. 12) una doble exposición para obtener un efecto multidimensional.

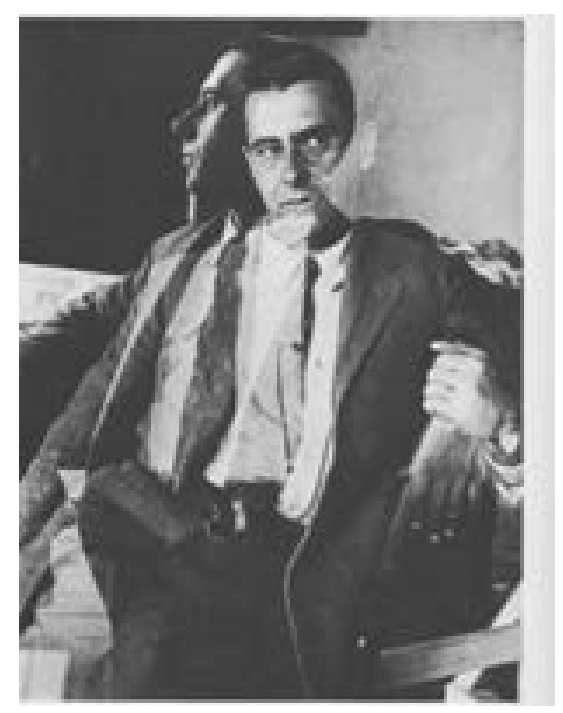

Fig. 12. Alexander Rodchenko. Retrato del artista Alexander Svenchenko, 1924.

El retrato, y el resto de los géneros tradicionales (el bodegón, el paisaje) eran especialmente queridos por los artistas de vanguardia, precisamente para demostrar que sus hallazgos no residían tanto en el descubrimiento de nuevas temáticas como en el de una nueva mirada sobre los objetos de siempre. Incluso las máquinas constituían, en cierta forma, una nueva clase de naturalezas muertas. Otra vez los fotógrafos abrieron nuevos caminos en su representación de las máquinas exponiendo las tripas abiertas de los artilugios modernos, demorándose en las líneas bruscas de las tuercas y los engranajes, en los brillos de los acabados metálicos y en la armonía involuntaria de sus formas mecánicas.

Además de la cronofotografía y el montaje, otras experiencias fotográficas (científicas, aéreas, telescópicas, microscópicas) proporcionaron a artistas modernos tan esenciales como Klee o Malevitch, entre otros, claves para poder desarrollar su arte. Malevitch, cuyo Suprematismo encontraba inspiración en la fotografía aérea, hacía referencias sucesivas a ello en El mundo sin objeto (1927) cuando señalaba las fotos del vuelo de una escuadrilla como motivo que le estimuló en su trabajo. Así mismo, una parte de la obra de Klee, a base de campos de diferente textura y color, manifiesta la influencia de la fotografía aérea.

Lászlò Moholy-Nagy fue profesor de la Bauhaus y un artista completo que recorrió todo el espectro de las opciones expresivas, desde las que empleaban materiales 
tradicionales (pintura, escultura) hasta las que se sustentaban en las nuevas tecnologías de la época y donde había una evidente preocupación por los problemas comunicativos: tipografía, diseño, fotografía, fotomontaje, cine.

Ante esta fotografía (Fig. 13) de Moholy-Nagy, el espectador no puede identificar de inmediato lo que en ella se le propone (un jardín nevado). El «objeto», un juego de círculos y rectángulos blancos y negros se muestra como una composición abstracta, carente de referente.

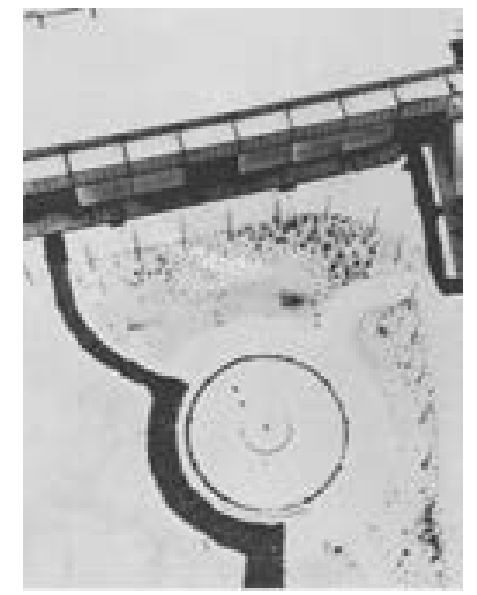

Fig. 13. Lászlò Moholy-Nagy. Sin título, 1928.

Más o menos al tiempo, otros fotógrafos, en este caso representantes de la Nueva Objetividad, en los años 20 presentaban un nuevo tipo de fotografía. Willy Zielke, por ejemplo, reduce al mínimo el tema de la fotografía, mediante series sobre un mismo tema, experimentando sobre un material y sus texturas.

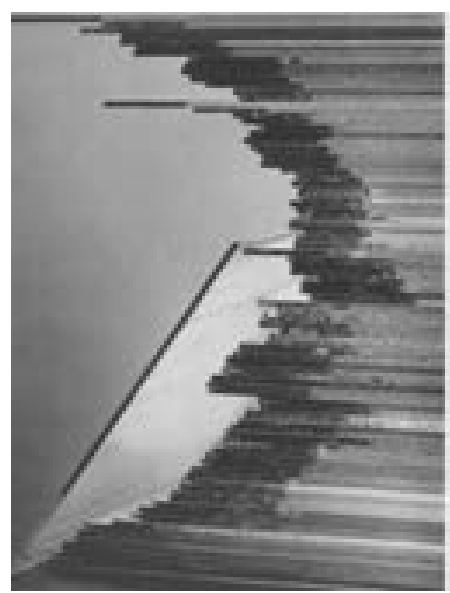

Fig. 14. Willy Zielke. Fotografía, 1929. 


\section{Cine $y$ arte del movimiento}

Si el siglo XX ha sido el fruto de la tecnología y del mercado de masas, entonces indudablemente el arte más característico del siglo pasado, ha sido el cine. Ninguno representa como él ese cruce entre una expresión fruto del avance tecnológico, en este caso en la ilusión del movimiento, y una aceptación incondicional de las masas. Una serie de factores tecnológicos (la fotografía, la electricidad), científicos (en el campo de la óptica y de la comprensión de la visión humana) y sociales (que van desde el interés que suscitaban en el XIX aquellas máquinas que simulaban el movimiento: el fenaquistoscopio, el zootropo, etc., hasta la emergencia de una demanda de tipo masivo) hicieron factible el cinematógrafo.

En el Teatro-praxinoscopio se contemplaba, a través de la boca de un escenario, la fuga de las imágenes reflejadas en los espejos del centro de un tambor. Con el Zoopraxiscopio de Muybridge se proyectaban, en 1880, imágenes en movimiento de animales. El cine perteneció en origen a este mismo rango de curiosidades científicas y artilugios chocantes. Los temas de las películas solían ser de índole popular y en los primeros años se buscaban escenas con mucho movimiento: danzas, combates o la famosa llegada del tren.

Entre los números de «varieté» gustaron mucho las danzas de los años 90, es decir aquellos bailes con banderas y gran movilidad tipo la danza mariposa. La película de Max Sladanowsky, filmada en 1896, contaba, por ejemplo, con la bailarina Mlle. Ançion, mientras que Edison produjo otra (Anabela la bailarina) para su Kinetoscopio con la artista Annabelle Withford Moore dentro del programa del Koster and Bial's Music Hall de Nueva York donde se presentó una primera proyección de sus películas el 13 de abril de 1896.

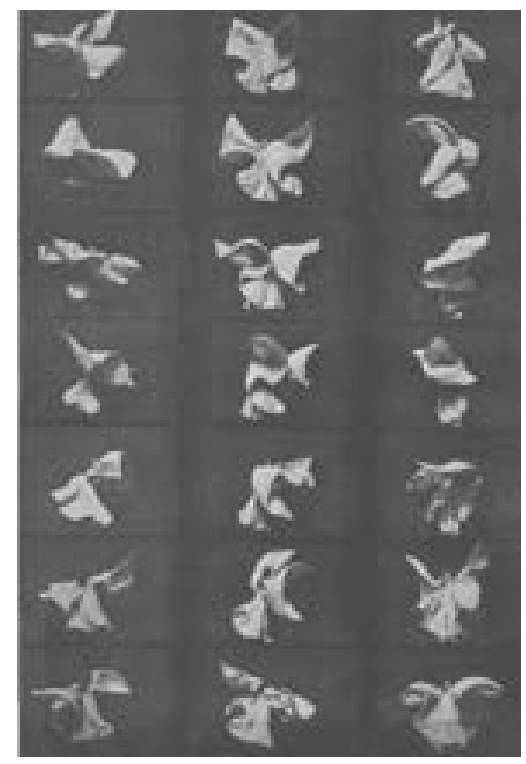

Fig. 15. Anabela la bailarina. 1896 
Tanto el estilo modernista, dominante en aquellos años en las artes gráficas y aplicadas, como el novedoso cinematógrafo favorecieron el gusto por los bailes ondulantes que querían semejar llamas, batir de alas u oleaje. Quizá la más famosa de estas damas fue Loïe Fuller, objeto de inspiración de algunos de los artistas de su época: Raoul Larche, realizó una retrato de la bailarina en forma de exquisito candelabro; The Serpentine Dance, 1894, de William H. Bradley y un cartel de G. Meunier, un discípulo de Chéret, fueron otras tantos intentos de representar los movimientos sinuosos de esta bailarina. El propio Chéret, Lautrec y Orazi también tuvieron a la Fuller entre sus modelos. Las formas ondulantes de los velos traslúcidos con los que cubría su cuerpo desnudo parecen repetirse en los motivos decorativos modernistas. Y la sugestión de la danza, y con ella la representación del tiempo, recorre los vasos de cristal, las cornisas, las estatuillas, los cuadros y carteles de los modernistas.

No resulta, por tanto, muy descabellado pensar que el primer impulso del cine se debió a toda esa atracción por el movimiento de la época modernista con la que coincidió en su nacimiento e intereses. Pero pasada una primera etapa de fascinación por el invento y de asombro ante la imagen en movimiento, fue el apoyo del gran público lo que empujó el cine para establecerse como una nueva forma artística.

Casi al mismo tiempo que el cubismo -nos dice Eric Hobsbawm ${ }^{13}$ - es decir, a partir de 1907, el cine empezó a utilizar una serie de técnicas (perspectiva múltiple, enfoques variables, montaje) que realmente familiarizaron a la población con una nueva forma de aprehender la realidad por medio de percepciones simultáneas o cuasi simultáneas de sus diferentes aspectos.

Ha habido muchos intentos, desde Eggeling (Vertikal-Horizontal Mass, 1919) o Hans Richter (Rythme 21, 1921) a Andy Warhol (Sleep, Empire, etc.), de hacer un cine experimental, poético, artístico; pero realmente incluso el cine más convencional de Hollywood es, desde un punto de vista técnico, mucho más revolucionario que cualquier tela cubista o futurista. Además, es difícil concebir un cine más experimental, más vanguardista «avant la lettre» que el de Méliès. En realidad todo arte, toda forma nueva de expresión sufre, en sus inicios, ese período de inevitable ensayo y observación hasta que consolida su propio lenguaje.

Una vez que se han constituido los códigos -y esa es la parte más difícil del asuntollega la fácil experimentación que consiste en destruirlos y que, en verdad, carece por completo de interés.

Los artificiosos intentos de los futuristas por introducir la máquina en la pintura, o los de convertir el arte en una ciencia a la manera de Kandinsky, la ambición de unas y otras vanguardias - y esencialmente de los constructivistas- por hacer un arte para las masas, hay que colocarlos en el cajón de las buenas intenciones, más que en el de las genuinas victorias. La primera mitad del siglo XX aparece repleta de buenos propósitos $\mathrm{y}$ proyectos frustrados. El verdadero arte de masas ha sido el cine y nada puede considerarse auténticamente revolucionario, en el siglo XX, sino ha sido favorecido por las masas. Por ello también, la fotografía, el fotomontaje y el cine han sido instrumentos propagandísticos mucho más eficaces que la pintura o la escultura.

${ }^{13}$ Hobsbawm, E. (1988): A la zaga. Decadencia y fracaso de las vanguardias del siglo XX, Madrid, Crítica, 32. 
Al margen de sus valores plásticos, la fotografía y el cine se mostraron por encima de los procesos, materiales y formatos tradicionales, no sólo como instrumentos de comunicación, sino para ofrecer al gran público una meditación, a su altura, sobre el espacio y el tiempo, es decir sobre aquellos aspectos que las vanguardias creían que constituían sus propias conquistas.

\section{Cassandre y el arte cinético}

Toda la fascinación por el mundo de la máquina, de la velocidad, del movimiento llega a su éxtasis con la creación del arte cinético. No se trataba de representar el dinamismo a la manera de los futuristas, ni tampoco de embelesarse por las máquinas a la manera de Leger. El cuadro tenía que ser una máquina en sí mismo.

La obcecación del arte del siglo XX por hacer suyo el movimiento ha sido persistente, así que realmente bajo la denominación de arte cinético se han podido englobar experiencias muy diferentes: la Rueda de bicicleta de Duchamp, el proyecto Monumento a la tercera internacional de Tatlin, la Construcción cinética de Gabo, los móviles de Calder, los experimentos de arte cinético luminoso, etc.

Probablemente la Rueda de bicicleta (1913) de Duchamp fue la primera obra realmente móvil. Vladimir Tatlin, por su parte, concibió, hacia 1919, su Monumento a la Tercera Internacional (del que sólo se conservan fotografías de la maqueta por lo que deviene así mismo en un precursor involuntario del conceptual) como una torre Eiffel proletaria. Varias partes debían pivotar sobre sus ejes a diferentes velocidades. Tatlin terminó de diseñador industrial en Rusia, donde probablemente pudo aplicar todos los conocimientos que había obtenido en sus experimentaciones de una manera mucho más funcional.

En la Construcción superficie desarrollable (1936) de Anton Pevsner, el juego de la luz sobre la superficie de una escultura abstracta transmite la impresión de movimiento. Hay ciertas concomitancias de esta obra con la de su hermano Naum Gabo Variación translúcida sobre un tema esférico (1937) en la que también las superficies, en este caso transparentes, se curvan para dar impresión de movimiento gracias, así mismo, a los efectos de la luz. Tanto esta pieza como la anterior, pertenecerían a un cinetismo óptico, donde el movimiento no es real sino un engaño del ojo.

Pero bajo el nombre de «arte cinético» se conoce sobre todo a las experiencias de arte óptico que surgen a partir de mediados de los años cincuenta.

El más conocido artista del cinetismo es Victor Vasarely, un pintor nacido en Hungría. Se trasladó a París en 1930, y hasta 1944 se dedicó a la publicidad, en las agencias Havas y Draeger, donde se especializó en obras que mostraban un interés por el trampantojo y las ilusiones espaciales. Todos estos trucos visuales fueron los que luego aplicó en su pintura. Hoy hay dos museos que llevan su nombre, aunque en realidad no hizo sino desarrollar y establecer como un nuevo arte lo que había aprendido del diseñador publicitario Cassandre, un nombre que sin embargo no suele aparecer en los manuales de arte al uso.

Cassandre fue el gran artista publicitario del período de entreguerras, justo cuando las vanguardias estaban en su punto máximo de ebullición. Proporcionó imágenes rotundas de los trenes, los trasatlánticos y el telégrafo; construyó, partiendo del cubismo 
y del surrealismo, un lenguaje de formas que era realmente capaz de comunicar (es decir que, como pedía David Hume, hermanaba la novelty, la novedad necesaria para atraer, y la facility para hacerse comprender) y se anticipó al arte cinético en piezas como Nicolas (1935). Consiguió, en definitiva, conciliar los aciertos de la vanguardia con el mercado y el público de masas.

Cassandre convirtió en accesible el espinoso lenguaje de futuristas y cubistas. Practicó un arte innovador y público al que no le hacían falta textos teóricos o críticos en los que apoyarse, porque su lenguaje era empíricamente -y no teóricamente como el de las vanguardias- un lenguaje de masas. Y se anticipó a la pintura cinética en anuncios como Dubo-Dubon-Dubonnet (1932) o Nicolas (1935). Hay mucho en común entre el anuncio de Cassandre y una pintura de Vasarely como Tigres tres años posterior.

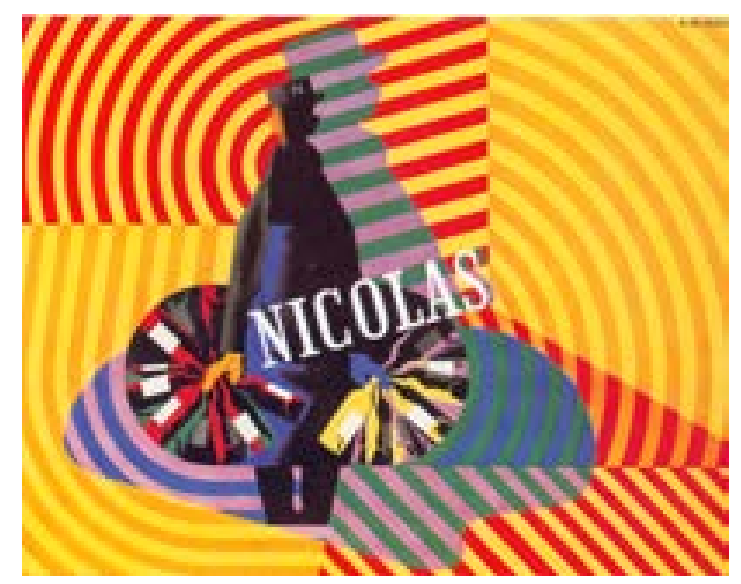

Fig. 16. Cassandre. Nicolas. 1935.

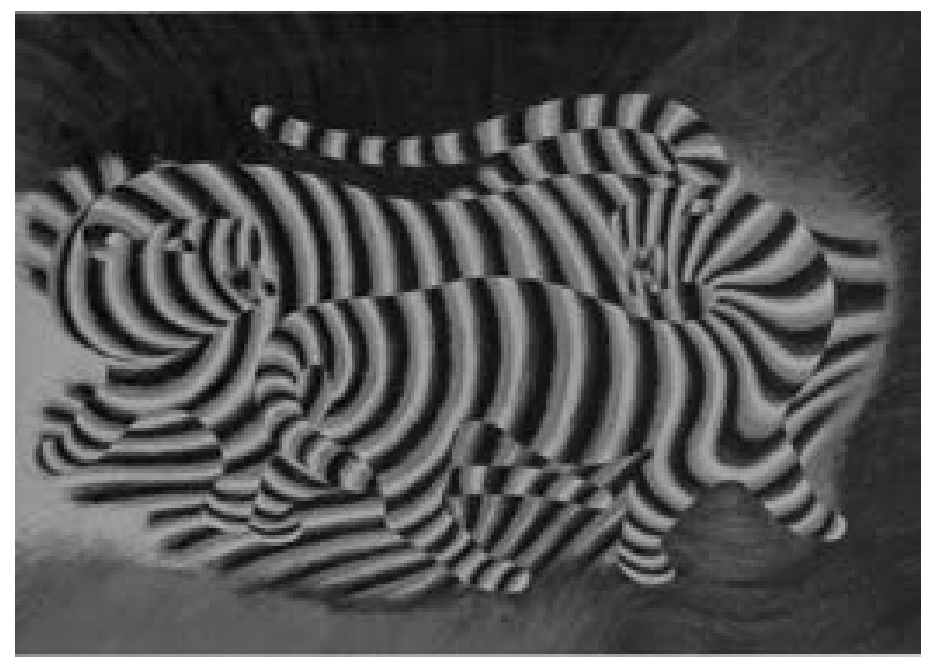

Fig. 17. Victor Vasarely. Tigres, 1938. 
La tragedia de la vanguardia es que produjo un lenguaje artístico incapaz de transmitir o de participar por sí solo y que, para hacerse explicar, ha necesitado -más que en ninguna otra época- de las palabras, es decir de un lenguaje convencional que fuese poniendo los comentarios a las obras. La inflación de la literatura crítica en el siglo XX ha sido, pues, una pesadez casi inevitable. La crítica se ha terminado por convertir en algo en sí mismo, por completo independiente de la obra que comenta (o perfectamente transferible de una a otra obra), mientras el artista ha intentado convertirse (casi siempre con unos resultados de una pobreza o una ingenuidad alarmantes) en crítico de sí mismo.

Frente a esta cargante retórica, Cassandre elaboró una obra sutil y compleja en su aparente simplicidad que sedujo no sólo a los viandantes de París, también al joven Vasarely. Según reconocía éste, un diseño de Cassandre para la imprenta «Deberny et Peignot» fue el que le puso en el camino de la que sería su forma de representación en 1931. El cartel representa las letras D y P como tipos fundidos de imprenta, en forma de dos cuadrados unidos por su base dibujados en perspectiva asonométrica: «Ambos dados tiraban violentamente de la bisagra que los mantenía unidos. Surgía así una impresión confusa que no satisfacía la percepción. Con un medio sencillo vivido ópticamente como paradoja, Cassandre supo desafiar la vista» ${ }^{14}$.

En realidad, no llegó a editarse nunca como cartel o anuncio pero sí que se utilizó reproducido en los camiones de reparto de la empresa.

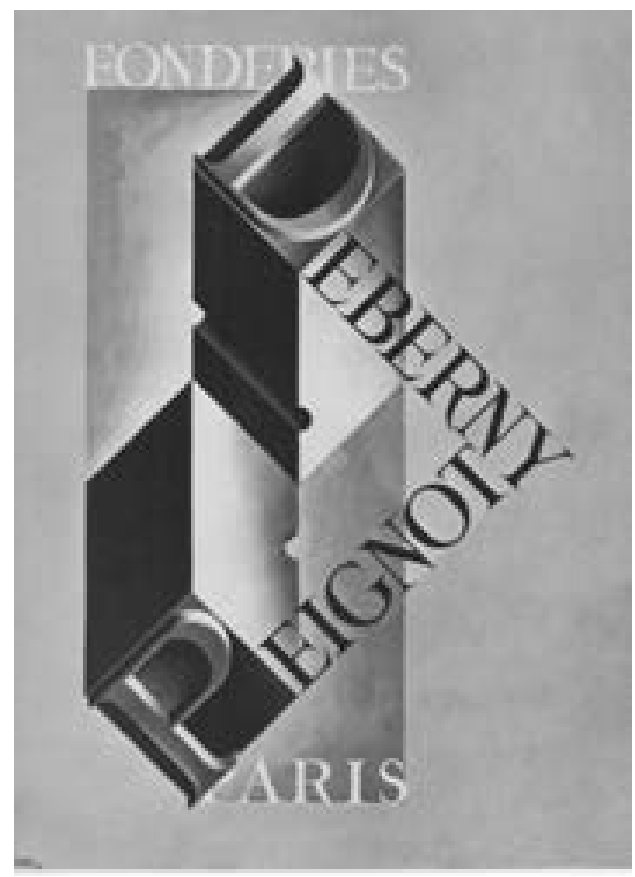

Fig. 18. Cassandre. Boceto de cartel para la imprenta Deberny et Peignot. 1929.

\footnotetext{
${ }^{14}$ Spies, W. Vasarely, Madrid, Fundación Juan March, 44-45
} 


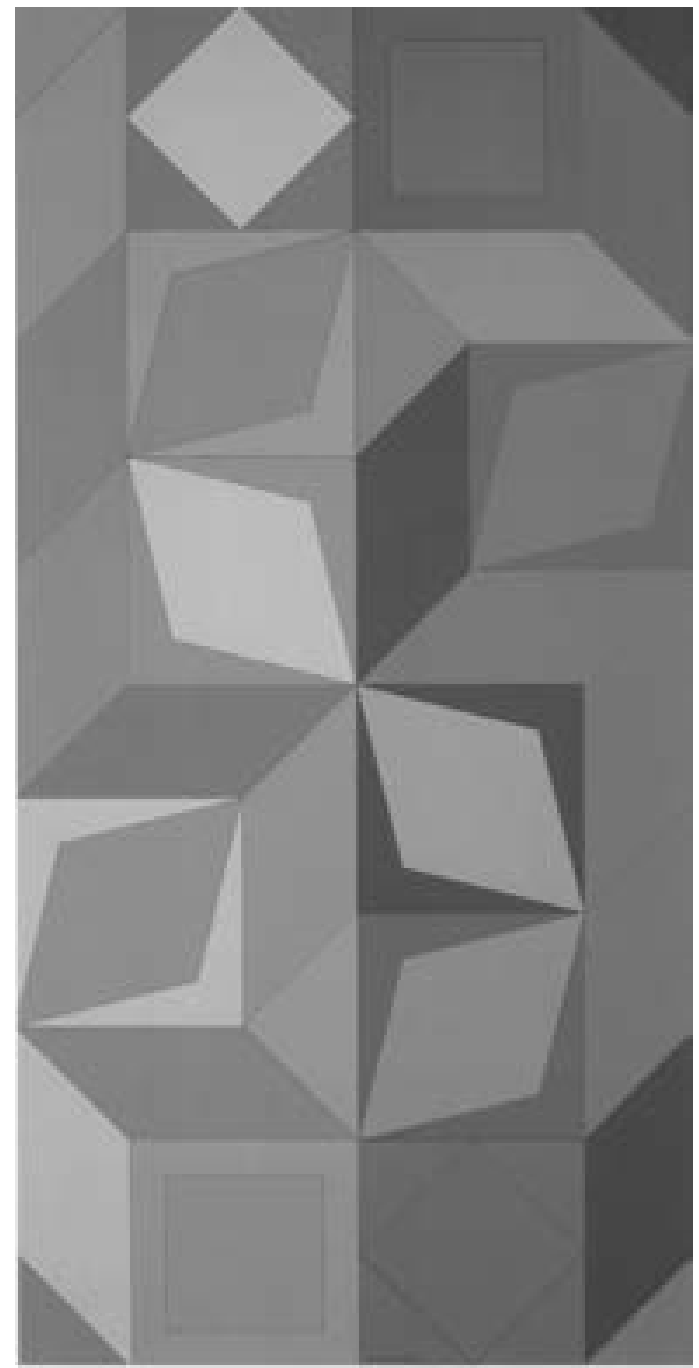

Fig. 19. Vasarely. Dom-Bleu. 1967.

Puede que en general sus carteles sean, como arte, menos transformadores que los cuadros cubistas o los del primer futurismo, pero aún así Cassandre y otros artistas publicitarios consiguieron triunfar donde la vanguardia mostraba severas limitaciones: en hacer comprensible una expresión del mundo moderno.

Algunos artistas más, de entreguerras, desarrollaron también en el campo publicitario un acercamiento paralelo a los lenguajes de vanguardia. Joel Martel, por ejemplo, convierte su cartel de 1926 para un espectáculo de baile en una composición basada en el círculo, cabalmente alejada del tratamiento modernista a parecidos temas, y que conecta con las experiencias de cubistas y futuristas. 


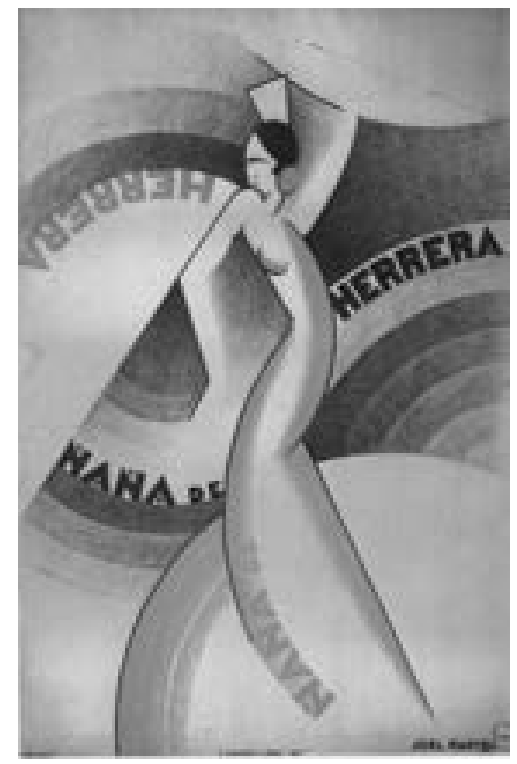

Fig. 20. J. Martel. Ñaña de Herrera. 1926.

Mientras que en Satomi la fascinación por la velocidad y la máquina de las vanguardias encuentra en su cartel de 1937 una expresión sumamente clara. Es el paisaje visto desde el interior del tren a toda marcha.

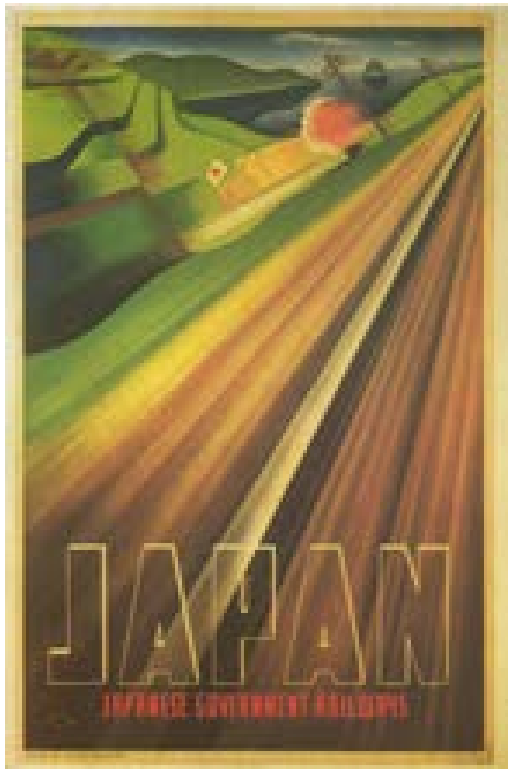

Fig. 21. Satomi. Japan. Japanese Government Railways. 1937. 
Si Cassandre representa un antecedente del arte cinético, estos ejemplos resultan tardíos respecto a las experiencias de los artistas de las primeras vanguardias, pero paralelas a otras de tipo simultaneista o vibracionista. Y a cambio se aproximan mucho mejor a la sensibilidad de un público mayoritario. A la hora de hacer llegar al gran público un lenguaje plástico transformador, estos carteles resultaban sin duda más enérgicos y competentes.

El caso es que ahora nos encontramos ante una disyuntiva semejante, de alguna manera, a aquella que se produjo en la segunda mitad del siglo XIX: un choque entre las formas de expresión y comunicación derivadas de una tecnología del pasado (cine, televisión, medios electrónicos) y otras que apuntan hacia el futuro (Internet, medios digitales). Es verdad que existen inevitables diferencias entre una y otra situación, pero no es menos cierto que analizar lo acaecido en el pasado es un procedimiento bastante sensato para no seguir menudeando en determinados errores. Y, por el contrario, estudiar un fenómeno en el que el propio observador se encuentra inmerso resulta, como es bien sabido, la mejor manera de tener una visión totalmente desenfocada del problema ${ }^{8}$.

El tiempo que nos aleja del problema, pues, nos proporciona una necesaria distancia epistemológica, una valiosa dosis de objetividad y una posible perspectiva de la cuestión. Podemos, a partir de esa experiencia, extraer dos conocimientos básicos. Primero que una tecnología superior acaba siempre desplazando a otra más antigua, por mucho que se hagan oír las voces apocalípticas de los nostálgicos y agoreros. Segunda, que ese proceso no se puede hacer sin víctimas, y que los detentadores de las tecnologías refractarias lucharán por mantener sus posiciones de privilegio frente a los depositarios de las tecnologías más avanzadas. Es pues un momento de conflicto, aunque este no se manifieste como una guerra convencional, pero también de oportunidades para aquellos más dinámicos o mejor adaptados, como también demuestra el pasado.

\section{Bibliografia}

Ash, R. (1991): Toulouse Lautrec. The Complete Posters, Londres, Bloomsbury Books. Barthes, R. (1970): "El mensaje fotográfico" en La Semiología, Buenos Aires, Tiempo Contemporáneo, 115-126.

Baudelaire, Сh. (1988): Curiosidades Estéticas, Barcelona, Júcar.

Charbonnier, J. M. \& Jover, M. (1991): Grandes lignes : quand l'art entre en gare, Paris, Publications Nuit et Jour

DoRfLEs, G. (1974): Las oscilaciones del gusto, Barcelona, Lumen.

Gombrich, E. H. (1982): Historia del arte, Madrid, Alianza Forma.

Hobsbawm, E. (1988): A la zaga. Decadencia y fracaso de las vanguardias del siglo $X X$, Madrid, Crítica.

Laclotte, M. (dir.) (1987): Diccionario Larousse de la pintura. Barcelona. Planeta-De Agostini.

${ }^{15}$ Ese tipo de razonamiento, tan característico de nuestra política, de «esto no se puede comprender desde fuera» resulta de una falacia y de una imprecisión científica insoportable. Es precisamente desde dentro desde donde no se puede observar un problema. 
Ramírez, J. A. (1988): Medios de masas e Historia del Arte, Madrid, Cuadernos Arte Cátedra.

SPIES, W. (2000): Vasarely, Madrid, Fundación Juan March

Varnedoe, K. \& Gopkin, A. (1991): High \& Low. Modern Art, Popular Culture, Nueva York, The Museum of Modern Art, 1991. 